\title{
The Effect of Cristiano Ronaldo's Recruitment on Football Club's Stock Prices In Italian League
}

\begin{abstract}
Panji Putranto
Universitas Mercu Buana

Abstract

Stock prices are not always influenced by financial factors, sometimes non-financial factors can also influence the fluctuation of stock prices. This study aimed to examine the effect of Cristiano Ronaldo's move from Real Madrid to Juventus on the stock prices of Italian league football clubs that go public. The sample used were the stock price of Juventus clubs, AS Roma, and Lazio. The stock price were tested by the stock price in 1-10 days before Ronaldo's move and stock prices 1-10 days after Ronaldo's move. This study used the paired sample T-Tes method. The results of this study indicated that Cristiano Ronaldo's had a significant effect on the rise of stock price for Italian League football clubs that listing in capital market.
\end{abstract}

Keywords: Critiano Ronaldo, Stock Price, Football Clubs, Juventus

DOI: $10.7176 / \mathrm{JESD} / 10-4-18$

\section{INTRODUCTION}

Football is the most interesting sport for people around the world. The popularity of football makes that sector into a promising industry. Hidayat (2010) argues that football has been growing very rapidly thus making it a very lucrative business, especially in the European leagues. The development of football in Europe has an impact on the earned by European football clubs, especially in high-reputed clubs (Rahman and Diyani, 2017).

The prospect of football business in Europe makes public interested in investing. Football clubs can be either private or open companies. Some football clubs that publish their stock in the capital market include Manchester United (England), Arsenal (England), Juventus (Italy), Lazio (Italy), Borussia Dortmund (Germany), Ajax Amsterdam (Netherlands, etc). https://www.footballbenchmark.com/stock exchange football clubs).

There are several prominent businessman who enter the football business including Alisher Usmanov (Arsenal), Roman Abramovich (Chelsea), Malcolm Glazer (Manchester United), and others (Pranata and Supatmi, 2014). In fact, Indonesian businessman Erick Thohir had acquired a 70\% shares of Italian football club Inter Milan before releasing his majority share to Chinese investor group, Suning Group.

Football clubs has the same purpose as the general companies, that's generate some profit. Haryoprasetyo and Kiswara (2013) argued that the football club's main income comes from sponsors, match tickets, and sales all of various kinds merchandise. Every football club wants to be able to meet the needs of stakeholders, one of which is shareholders. Nordiana and Budianto (2017) argued that companies may be called successfully manage their business, if the stock price are continues increase, so that investors can assess that the company is well-managed.

Football players are an important element of football clubs. Football players can be considered as the most important and most valuable asset for the club (Rahman and Diyani, 2017). Devi (2004) argued that the treatment of football players as assets is still debated, but in football industry the players are aspects that provide added value to the club. The popularity of football players will raise the prestige of the club which he built. This time, the reason clubs of buying players is not only because of the quality game offered by the player, but also from the player's popularity. This happened when Real Madrid bought David Beckham and Cristiano Ronaldo from Manchester United (Hidayat, 2010).

The phenomenon that is currently trending is the transfering of Cristiano Ronaldo from Real Madrid (Spain) to Juventus (Italy). Juventus dare poured funds amounting $£ 105.3$ million to players who are aged 33 years (https://www.transfermarkt.co.uk). Juventus certainly have their own considerations in recruiting Cristiano Ronaldo from Real Madrid. Ronaldo has won the World's Best Player award at 5 (five) times (www.juventus.com), so his ability to do the ball is undoubted. Another consideration besides his ability is of course the popularity of Cristiano Ronaldo. According www.businessinsider.sg page, Cristiano Ronaldo is the most popular player in 2018, which is marked by a total followers of 121.7 million on one of his social media accounts. Cristiano Ronaldo's popularity was too great even have an impact on stock prices of Juventus, even though at that time the move was still just a rumor. The issue of Ronaldo's move from Real Madrid to Juventus began to strengthen on 4 - 9 July 2018 after Ronaldo failed to bring Portugal to win the World Cup. Reporting from www.cnnindonesia.com, at that time stock price of Juventus shot up to 9 percent at $€ 0.81$ or around Rp13,625.82 per share. After the rumors came true, Juventus stock prices soared. Cristiano Ronaldo's reputation not only raised the prestige of Juventus, but also the Italian League as a whole. This is the main focus of this research. 
Research on the testing of the company's stock price changes using event study has done several times before. The research conducted by Saputra (2017) found that there are differences in stock prices of companies that listed on IDX before and after the date of stock split announcement.

The research of Barokah and Witiastuti (2016) concluded that there were no abnormal stock return when 15 days before the MNC36 index launch date, no abnormal stock return when 15 days after the MNC36 index launch date, and there were no difference in abnormal stock returns during the 15 days before and after the MNC36 index launch date. While the research of Indiarti and Purba (2011) obtained results that 1) found a significant difference in the average stock price at the time before and after the announcement of the stock split; 2) There is a significant difference between trading volume before and after the stock split phenomenon. According to Mulyana (in Iskandar, 2015:92), the trading volume of activity is defined as "the instrument that can be used to see the market reaction to a movement parameter information through the activity of trading volume in the stock market."

The difference between this research and prior research are the object of research and the phenomena being tested. This study aims to examine whether there are differences in the stock prices of Italian League football clubs that go public when 1-10 days before Cristiano Ronaldo's transfer, and 1-10 days after the transfer of Cristiano Ronaldo has been realized. The research also aims to assess the attraction of Cristiano Ronaldo as the most popular football player in the world so that it has an impact on the stock prices of football clubs in Italy. Based on the background above, the following hypothesis is tested:

$\mathrm{H}_{1}=$ There are differences in the stock prices of Italian League football clubs that go public before and after Cristiano Ronaldo's move from Real Madrid.

\section{RESEARCH METHODS}

This research is a study that analyzes the market reactions to the phenomena that occur. This study aims to determine whether there are differences in the stock prices of Italian League football clubs when 1-10 days before the move of Cristiano Ronaldo and 1-10 days after the move of Cristiano Ronaldo was realized.

This study uses a quantitative approach. Stock prices of Italian League football clubs are tested using the paired sample T-Test and using SPSS 25 version. Football clubs that go public in the Italian League are Juventus, AS Roma, and Lazio (https: // finance. yahoo.com).

\section{RESEARCH RESULTS AND DISCUSSION}

Juventus, AS Roma, and Lazio are three Italian league football clubs that issue shares in the capital market. The following is the average stock price of Juventus, AS Roma, and Lazio in 1-10 days before the move of Cristiano Ronaldo from Real Madrid..

Table 1 Average Stock Prices of Juventus, AS Roma, and Lazio in 1-10 Days Before Cristiano Ronaldo's Move (in Euros)

\begin{tabular}{cc}
\hline Day & Stock Price \\
\hline-10 & 0,85200 \\
-9 & 0,85200 \\
-8 & 0,85367 \\
-7 & 0,85533 \\
-6 & 0,86633 \\
-5 & 0,93667 \\
-4 & 0,94700 \\
-3 & 0,94700 \\
-2 & 0,94700 \\
-1 & 0,96667 \\
$\mathbf{1}$ & $\mathbf{1 , 0 1 5 0 0}$ \\
\hline
\end{tabular}

Source: https://finance.yahoo.com processed by researchers

The issue of Ronaldo's move blows around 4 - 9 July 2018. Stock is an instrument that is most easily affected by the emergence of an issue. Table 1 shows that the average price of stock of all three clubs has increased every day, which means that the stock prices of the three clubs were affected by the issue of Cristiano Ronaldo's move to Juventus. Cristiano Ronaldo officially joins Juventus on 10 July 2018.

The average stock price of that three clubs in 1-10 days after Cristiano Ronaldo officially joined Juventus are as follows: 
Table 2 Average Stock Prices of Juventus, AS Roma, and Lazio in 1-10 Days After Cristiano Ronaldo's

\begin{tabular}{cc}
\multicolumn{2}{c}{ Move (in Euros) } \\
\hline Day & Stock Price \\
\hline $\mathbf{1}$ & $\mathbf{1 , 0 1 5 0 0}$ \\
+1 & 1,01167 \\
+2 & 0,96500 \\
+3 & 0,98367 \\
+4 & 0,98367 \\
+5 & 0,98367 \\
+6 & 0,99600 \\
+7 & 1,00100 \\
+8 & 1,02467 \\
+9 & 1,04167 \\
+10 & 1,05333 \\
\hline
\end{tabular}

Source: https://finance.yahoo.com processed by researchers

Table 2 shows that the average stock price of the three clubs in 1 - 10 days after Ronaldo's move to Juventus was quite high. The peak is day one $(\mathrm{D}+1)$ after Ronaldo's recruitment, the average stock price of that three clubs reached $€ 1.05333$, which means investors are captivated by the presence of Cristiano Ronaldo in the Italian League Football and impact on the quick stock movement of that three clubs. The results of statistical calculations using the Paired Sample T-Test are as follows:

Table 3 Average Stock Prices of Juventus, AS Roma, and Lazio Before and After Cristiano Ronaldo's Move

\begin{tabular}{lll|r|r|r}
\hline \multicolumn{6}{c}{ Paired Samples Statistics } \\
\hline \multirow{2}{*}{ Pair 1 } & Mean & N & \multicolumn{1}{c}{ Std. Deviation } & Std. Error Mean \\
\cline { 2 - 7 } & Before & 0,9023670 & 10 & 0,04971485 & 0,01572122 \\
\cline { 2 - 7 } & After & 1,0044350 & 10 & 0,02822645 & 0,00892599 \\
\hline
\end{tabular}

Source: SPSS 25 Processing Results

Table 3 shows that the average price of a stock of all three clubs before Cristiano Ronaldo's move from Real Madrid to Juventus was $€ 0.90237$. While the average price of a stock of the three clubs after the move of Cristiano Ronaldo was $€ 1,00443$. It can be concluded that Cristiano Ronaldo's move to Juventus or the Italian League made investors interested in investing his money into the Italian League, especially Juventus, which is Ronaldo's new club.

Furthermore, the following is the calculation of the paired sample correlation of stock prices before and after Cristiano Ronaldo joined Juventus.

Table 4 Calculation of Paired Sample Correlation in Stock Prices Before and After Cristiano Ronaldo's

Move

\begin{tabular}{llr|r|r}
\hline \multicolumn{5}{c}{ Paired Samples Correlations } \\
\hline & $\mathrm{N}$ & Correlation & \multicolumn{1}{c}{ Sig. } \\
\hline Pair 1 & Before \& After & 10 & 0,762 &, 010 \\
\hline
\end{tabular}

Source: SPSS 25 Processing Results

Table 4 shows that the calculation of paired sample correlation of stock prices before and after Cristiano Ronaldo joined Juventus has a correlation value of 0.762 and has a significance level of 0.010 or $<0.05$. Based on these results it can be concluded that there is a correlation between samples, which means that the effect of Ronaldo's move to Juventus influences changes in the stock prices of Italian League Football clubs that go public.

\section{Hypothesis Test Results}

Hypothesis testing is done by using Paired Sample T-Test. The T-Test serves to answer the hypothesis. The hypothesis in this study is "There are a differences in the stock prices of Italian League football clubs that go public before and after Cristiano Ronaldo's move from Real Madrid". Hypothesis testing is done using the Paired Sample T-Test by comparing the stock prices of football clubs when $1-10$ days before Ronaldo's move with stock prices 1 - 10 days after Ronaldo's move to Juventus.

The results of the Paired Sample T-Test are as follows: 
Table 5 Paired Sample T-Test Results Before and After Cristiano Ronaldo's Move Paired Samples Test

\begin{tabular}{|c|c|c|c|c|c|c|c|c|c|}
\hline \multicolumn{10}{|c|}{ Paired Samples Test } \\
\hline & & \multicolumn{5}{|c|}{ Paired Differences } & \multirow{3}{*}{$\mathrm{t}$} & \multirow{3}{*}{ Df } & \multirow{3}{*}{$\begin{array}{l}\text { Sig. (2- } \\
\text { tailed) }\end{array}$} \\
\hline & & \multirow[t]{2}{*}{ Mean } & \multirow[t]{2}{*}{$\begin{array}{c}\text { Std. } \\
\text { Deviation }\end{array}$} & \multirow[t]{2}{*}{$\begin{array}{l}\text { Std. Error } \\
\text { Mean }\end{array}$} & \multicolumn{2}{|c|}{$\begin{array}{l}95 \% \text { Confidence } \\
\text { Interval of the } \\
\text { Difference }\end{array}$} & & & \\
\hline & & & & & Lower & Upper & & & \\
\hline $\begin{array}{c}\text { Pair } \\
1\end{array}$ & $\begin{array}{c}\text { Before- } \\
\text { After }\end{array}$ & $-0,10206800$ & $\begin{array}{c}0,0336082 \\
3\end{array}$ & $\begin{array}{c}0,0106278 \\
5\end{array}$ & $\begin{array}{c}- \\
0,1261098 \\
8\end{array}$ & $\begin{array}{c}- \\
0,0780261 \\
2\end{array}$ & $\begin{array}{c}- \\
9,604\end{array}$ & 9 & 0,000 \\
\hline
\end{tabular}

Source: SPSS 25 Processing Results

Table 5 shows that the calculated $t$ value in this study is -9.604 with a significance level of 0,000 or smaller than 0.005 . It can be concluded that $\mathrm{H}_{1}$ which states that "There are differences in the stock prices of Italian League football clubs that go public before and after Cristiano Ronaldo's move from Real Madrid" is acceptable.

\section{Discussion}

Stock is an instrument that is most easily affected by the emergence of an issue. Factors that make stock prices rise or fall are not only limited to financial factors, but sometimes also non-financial factors. The results of this study indicate that there was a significant change in stock prices for Italian League football clubs that go public (Juventus, AS Roma and Lazio) after the issue of Cristiano Ronaldo's move to Juventus appeared. The results of this study indicate that the average price of a share when 1-10 days before Ronaldo's move was equal to $€ 0.9023670$, then increased to $€ 1.0044350$ after Ronaldo officially joined Juventus. The average price per share increased by $10.21 \%$. The Paired Sample T-Test results show that the calculated t value in this study is -9.604 with a significance level of 0,000 or smaller than 0.005 , which means $\mathrm{H}_{1}$ is acceptable. Cristiano Ronaldo as the most popular football player and one of the best players in the world has a special attraction for Juventus and the Italian Football League, these factors make investors interested to investing in Italian League football clubs that go public. It can be concluded that the market value of football players is not only depend on the player's playing ability, but also the attraction or charm of the player outside the field.

Juventus made a brave decision by purchasing Cristiano Ronaldo from Real Madrid for $£ 105,300,000$ because he was 33 years old. However, the move was a smart move because the issue of Ronaldo's move had an effect on the stock price of Juventus and other Italian League clubs, which then surged after Ronaldo officially joined. The benefits offered by Ronaldo outside of his football skills are also a consideration for Juventus, such as attracting sponsors, increasing ticket sales, and selling many football jersey and Juventus merchandise related to Ronaldo. The results of this study indicate that the move of Cristiano Ronaldo from Real Madrid to Juventus had an effect on the rising stock prices of Italian football clubs that go public.

\section{CONCLUSION}

The Paired Sample T-Test results show that the calculated t value in this study is -9.604 with a significance level of 0,000 or smaller than 0.005 , which means $\mathrm{H}_{1}$ is acceptable. The results of this study indicate that the move of Cristiano Ronaldo from Real Madrid to Juventus had an effect on the rising stock prices of Italian football clubs that go public. Cristiano Ronaldo as a very popular and talented football player, and 5 times chosen to be the best football player can raise the prestige or standards of Juventus and other clubs in Italy. The results of this study also confirm that not only financial factors can affect the stock price of a company (or club), but non-financial factors can also affect the stock prices, one of which is human capital.

\section{DAFTAR PUSTAKA}

Barokah, S. and Witiastuti, R.S., 2016. Pengujian Abnormal Return Saham Sebelum dan Sesudah Peluncuran Indeks MNC36 (. Management Analysis Journal, 5(2).

Business Insider. 2018. The 18 Most Famous Athletes in the World in 2018. (https://www.businessinsider.sg/mostfamous-athletes-in-the-world-2018-5/?r=US\&IR=T). Diakses pada 11 November 2018.

Devi, A.P., 2004. Akuntansi Untuk Pemain Sepak Bola. Jurnal Akuntansi dan Keuangan Indonesia, 1(1), pp.3853.

Football Benchmark. 2017. Football Clubs and the Stock Exchange in 2016. (https://www.footballbenchmark.com/stock_exchange_football_clubs). Diakses pada 2 November 2018.

Haryoprasetyo, R. and Kiswara, E., 2013. Analisis Atas Kinerja Finansial Klub Sepakbola Profesional (Studi Kasus pada Manchester United PLC) (Doctoral dissertation, Fakultas Ekonomika dan Bisnis). 
Hidayat RT. 2010. “Analisis Atas Laporan Keuangan Klub Sepak Bola: Studi Pada Klub Arsenal, Juventus dan Barcelona”. Jakarta: Tesis Universitas Indonesia.

Indarti, I. and Purba, D.M.B., 2012. Analisis perbandingan harga saham dan volume perdagangan saham sebelum dan sesudah stock split. Jurnal Ilmu Ekonomi ASET, 13(1).

Iskandar, Diah. 2015. Efek Arus Kas Operasi, Laba Akuntansi, Return On Asset, Earning Per Share Terhadap Trading Volume Activity yang Terdaftar pada Bursa Efek Indonesia.. Teropong Jurnal Manajemen dan Bisnis. Vol. 6, No. 3, November 2015

Juventus. 2018. Cristiano Ronaldo. (http:/www.juventus.com/en/teams/first-team/forwards/cristianoronaldo/index.php). Diakses pada 5 November 2018.

Nordiana, A. and Budiyanto, B., 2017. Pengaruh Der, Roa Dan Roe Terhadap Harga Saham Pada Perusahaan Food And Beverage. Jurnal Ilmu \& Riset Manajemen, 6 (2).

Pranata EC, Supatmi. 2014. Analisis Kinerja Keuangan Pada Klub Sepak Bola (Studi Kasus Pada Arsenal, Tottenham Hotspur, Dan Everton). Jurnal Ekonomi dan Bisnis. Vol. XVII, No. 2, Agustus 2014

Rahman HA, Diyani LA. 2017. Kinerja Keuangan Klub-Klub Sepak Bola di Liga Inggris. Prosiding Seminar Nasional FPTVI 2017.

Saputra, I., 2017. Perbedaan Harga Saham Sebelum dan Sesudah Pengumuman Stock Split Pada Perusahaan Yang Listing di Bursa Efek Indonesia Periode 2008-2013. Dinamika Ekonomi-Jurnal Ekonomi dan Bisnis, 10(1), pp.14-26.

Sumirat S. 2018. Isu Transfer Cristiano Ronaldo Naikkan Saham Juventus. (https://www.cnnindonesia.com/olahraga/20180705224232-142-311907/isu-transfer-cristiano-ronaldonaikkan-saham-juventus). Diakses pada 12 November 2018.

Transfermarkt. 2018. Cristiano Ronaldo. (https://www.transfermarkt.co.uk/cristiano-ronaldo/profil/spieler/8198). Diakses pada 5 November 2018.

Yahoo Finance. 2018. Harga Saham. (https://finance.yahoo.com/). Diakses pada 20 November 018. 